\title{
混合チャンバーの空気力学的特性の研究 STUDY ON AERODYNAMIC CHARACTERISTICS OF A MIXING CHAMBER
}

\author{
橋本幸博*1, 柳原 茂*2, 吉野 一*3, 登坂宣好*4 \\ Yukihiro HASHIMOTO, Shigeru YANAGIHARA, Hajime YOSHINO \\ and Nobuyoshi TOSAKA
}

\begin{abstract}
This paper investigates aerodynamic characteristics of a mixing chamber for an air-handling unit by experimental and numerical methods. A mixing chamber is employed to mix return air (RA) and outside air (OA). A RA duct and an OA duct are connected to surfaces of a mixing chamber in different ways. Insufficient mixing of $\mathrm{RA}$ and $\mathrm{OA}$ may occur if the connecting way is inappropriate. It can produce uneven flow to coils of an air-handling unit and decrease heat exchange efficiency between airflow and water flow. This study discusses how mixing effectiveness of RA and OA depends on connecting ways of both ducts to a mixing chamber.
\end{abstract}

Keywords: Mixing Chamber, Air-handling Unit, Flow Visualization, CFD 混合チャンバー、エアハンドリング・ユニット、気流可視化、CFD

1. はじめに

・空調設備に用いるエアハンドリング・ュニットには混合チャンバ 一という箱状の部分があり、外気ダクトと還気ダクトが接続されて、 その中で外気と還気が混合するようになっている1。外気ダクトと 還気ダクトは、機械室の納まりなどから混合チャンバーの上面また は側面に接続される。この接続の組み合わせによっては、混合チャ ンバー内部で外気と還気がうまく混合せずに偏流を起こして冷却コ イルや加熱コイルに流入するため、コイルの熱交換効率が低下する 可能性がある。また、特にクリーンルーム系統に用いるときには、 混合チャンバー出口に設置するプレフィルターのフィルター効率が、 偏流により低下したり、フィルターの劣化が不均一になる色険性も ある。そして、寒冷地で冬期空調運転を行うとき、低温外気と還気 がうまく混合しないと、コイルの凍結を起こしたり、凍結防止サ一 モスタットが誤動作をする危険性がある 2)。そのため、混合チャン バー内部で気流が十分に摫䢁されているかを確認することは重要な ことである。ところが、エアハンンドリング・ユニットへのダクト接 続方法は主として施工上の利便性により決定されることが多く、接 続方法の指針を示す文献は極めて少ない。また、2 方向からチャン バーへ流入する気流の混合状態を調べた文献も少ない。 Robinson(1998)31は、外気ダクトの平行翼ダンパーの角度を変える ことにより、定風量エアハンドリング・ユニットにおけるフィルタ 一付き混合チャンバーの混合効率を実験的に調べている。
Robinson(1999)4)はフィルターの有無及び外気ダクト・還気ダクト のダンパー角度をパラメーターとして、同様に混合チャンバーの混 合効率を実験的に調查している。しかしながら、ダクト接続方法に 関する研究は行っていない。

本報では、外気ダクトと還気ダクトの混合チャンバーへの接続の 組み合わせによる混合状態の比較を模型実験と CFD（数值流体力 学）により検証する。模型実験では、主として流動パラフィン煙を トレーサーに用いた気流可視化実験による定性的な把握と空気温度 分布計測による定量的な把握により、気流の混合状態を確認する。 また、混合チャンバーへのダクト接続方法による局部抵抗倸数の相 違を比較して、送風機静圧に対してダクト接続方法がどのような影 響を与えるか考察する。また、CFDにより模型実験の結果と比較を 行い、結果の妥当性を考察する。以上から、混合チャンバーにダク トを接続するための最適な方法を検討する。

本研究は、日本建築学会大会学術講演会で発表した内容 556)7)に検 討を加えたものである。

\section{2. 実験の概要}

透明アクリル板を用いて混合チャンバーの縮小模型を作成し、こ れに外気ダクトと還気ダクトを模擬したダクトを接続する。混合チ ヤンバーの寸法は、 $400 \mathrm{~W} \times 200 \mathrm{H} \times 200 \mathrm{D}$ とし、それに接続するダ クト寸法を $100 \times 100$ の断面、長さ $450 \mathrm{~mm}$ とする。すべての寸法
*1 職業能力開発総合大学校建築工学科 助教授. 博士 (工学)

*2 東洋熱工業㑣技術統轄本部技術研究所

*3 東洋熱工業侏技術統轄本部技術研究所 博士 (工学)

*4 日本大学生産工学部数理工学科 教授. 工博
Assoc. Prof., Dept. of Architecture, Polytechnic Univ., Dr. Eng.

Technical Research Institute, Tonets Corporation

Technical Research Institute, Tonets Corporation, Dr. Eng.

Prof., College of Industrial Tech., Nihon Univ., Dr. Eng. 
が簡単な整数比になるようにする。混合チャンバー出口には、プ レフィルター（重量法 90\%程度）を設ける。

気流可視化には煙発生器を用い、一方のダクト（INLET1）か ら流動パラフィンを加熱して得られる煙を混合チャンバー一流入 させる。もう一方のダクト（INLET2）には煙を流入しない。混 合チャンバーの中央水平断面を Ar レーザーライトシートで照射 して、チャンバー下方からデジタル・ビデオカメラで撮影する。 図 1 に気流可視化実験装置の概要を示す。

気流の混合状態を定量的に比較するために、一方のダクト (INLET2) から流入する空気を電気ヒーターで加熱して $40^{\circ} \mathrm{C}$ 程 度とし、もう一方のダクト（INLET1）から流入する空気は常温

$\left(25^{\circ} \mathrm{C}\right.$ 程度）とする。混合チャンバー出口平面に熱電対を 21 点 配置して、データロガーで空気温度分布を計測する。計測のサン プリング周期は 1 分とし、60 個のデータを採取する。図 2 に実験 装置の概要を示し、図 3 に混合チャンバー出口空気温度分布計測 ポイントを示す。図 4 にダクト接続方法をケース分けして示す。

ダクト内中心風速を熱線式風速計で計測して、ダクト寸法（一 辺 $\mathrm{D}=0.1 \mathrm{~m}$ ）を代表長さとした Reynolds 数が $\mathrm{Re}=5000 、 10000$ 、 15000、20000 となるようにダクト内中心風速を調整する。ダク ト中心風速を計測しながら、ファンに印加される電圧をスライド 式変圧器で調整することにより、風速を目標值に合わせる。2 個 のダクト（INLET1 及びINLET2）内部風速は、温度による動粘 性係数の変化を考慮して決定する。基本的には、いずれの Reynolds 数のときも、2 個のダクトの風量比は約 1:1 である。

ダクト接続方法による圧力損失の大小を比較するために、図 2 に示すようにダクト断面中央部にピトー管を設置して、室内圧と

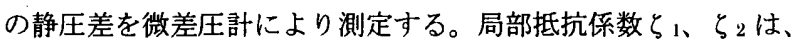
次式にて算出する ${ }^{8)}$ 。

$$
\begin{aligned}
& \zeta_{1}=\frac{\Delta p_{s 1}}{1 / 2 \rho v_{1}^{2}} \\
& \zeta_{2}=\frac{\Delta p_{s 2}}{1 / 2 \rho v_{2}{ }^{2}}
\end{aligned}
$$

また、混合チャンバーの総合抵抗係数 $\zeta_{T}$ を次式で定義する。

$$
\begin{aligned}
\Delta p_{T} & =\Delta p_{s 1}+\Delta p_{s 2}+\frac{1}{2} \rho\left\{\left(v_{1}^{2}+v_{2}^{2}\right)-2 v_{o}^{2}\right\} \\
\zeta_{T} & =\frac{\Delta p_{T}}{1 / 2 v_{m}^{2}}
\end{aligned}
$$

ここで、

$\rho:$ 空気の密度 $\left[\mathrm{kg} / \mathrm{m}^{3}\right]$

$\mathrm{v}_{1}:$ INLET 1 のダク, ト内風速 $[\mathrm{m} / \mathrm{s}]$

$\mathrm{v}_{2}:$ INLET2 のダクト内風速 $[\mathrm{m} / \mathrm{s}]$

$\mathrm{v}_{\mathrm{m}}: \mathrm{v}_{1} 、 \mathrm{v}_{2}$ の平均值 $[\mathrm{m} / \mathrm{s}]$

$v_{o}$ : 混合チャンバー出口空気の空間平均風速 $[\mathrm{m} / \mathrm{s}]$

$\Delta \mathrm{p}_{\mathbf{1} 1}$ : INLET1 内部と室内圧の静圧差 $[\mathrm{Pa}]$

$\Delta \mathrm{p}_{\mathrm{s} 2}$ : INLET2 内部と室内压の静圧差 $[\mathrm{Pa}]$ である。

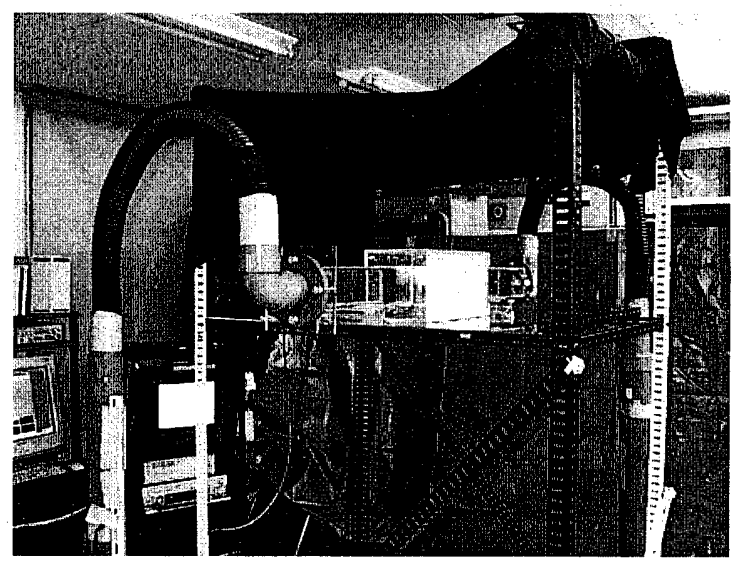

図 1 気流可視化実験装置

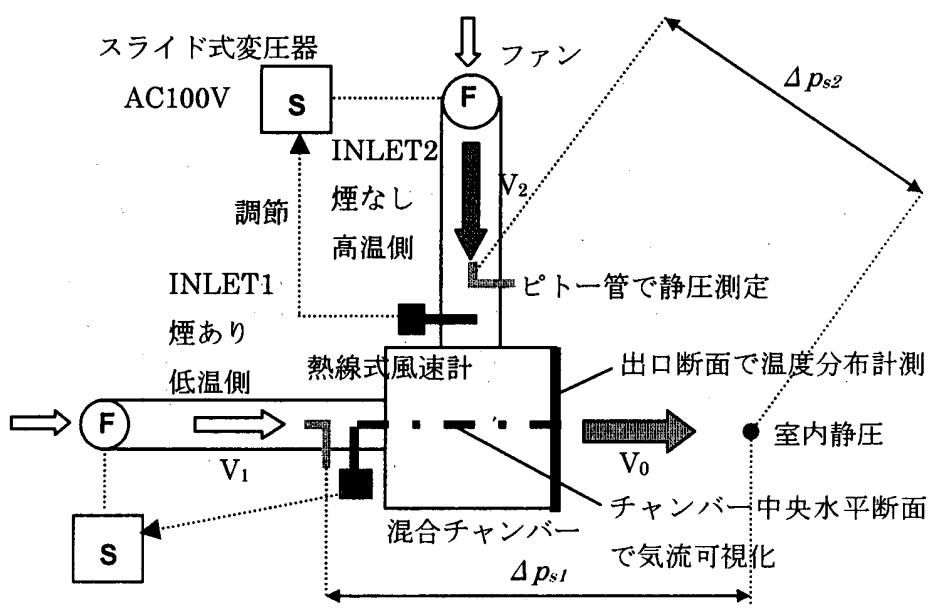

図 2 実験装置の概要 (CASE3 立面図)

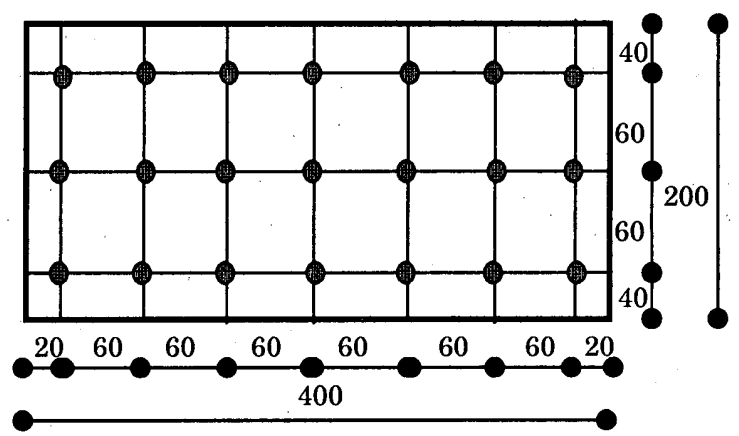

図 3 混合チャンバー出口温度分布計測ポイント

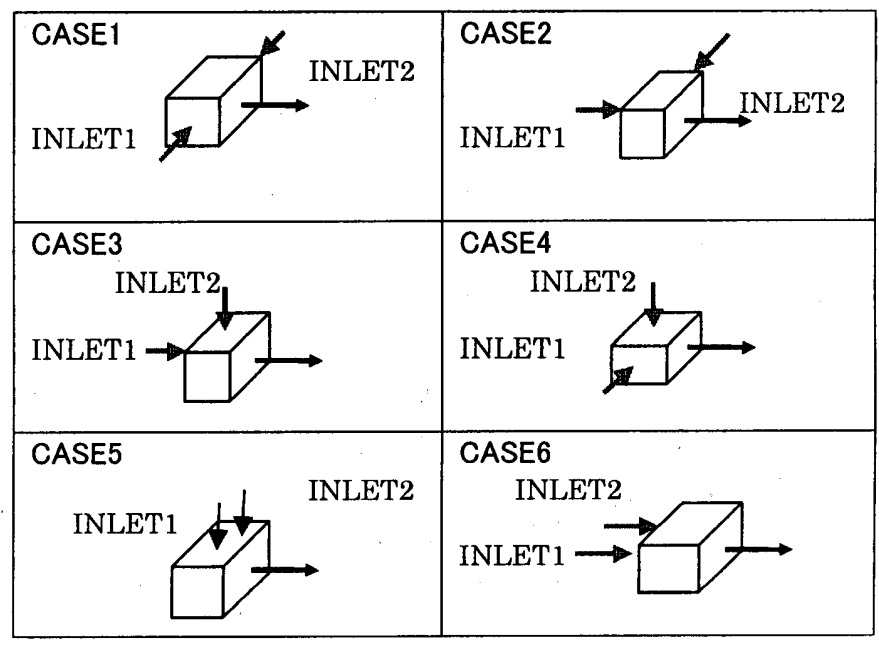

図 4 ダクト接続方法 
総合抵抗係数は、混合チャンバーによる動圧と静圧の損失の総和 を入口側平均動圧と比較した值であり、混合チャンバーによるエネ ルギー損失を動圧で正規化した值である。これは、流体のエネルギ 一保存則であるべルヌーイの式をもとにして、定義した係数であり、 混合チャンバーに接続する外気ダクト及び還気ダクト系両方の圧力 損失を評価するためにのみ用いる (Appendix 参照)。

\section{3. 実験結果}

\section{1 気流可視化実験}

気流可視化実験の結果を CASE（ダクト接続方法）ごとに図 5 に 示す。気流を矢印で、概略のチャンバー出口風速分布を曲線で示す。 混合チャンバー内部の流れ場の構造は、基本的に 2 方向からの噴流 の衝突または剪断流である。単独の噴流では、バックステップ乱流 であるが、混合チャンバー流入後直ちにもう一つの噴流と遭遇する ため、バックステップによる剥離の影響や乱流境界層の影響は無視 できるものと考えられる。ここでは、二つの角型噴流による乱流混 合に焦点を当てて、混合チャンバー内部の流れ場を観察する 910)。

\section{[CASE1]}

角型噴流が 2 方向から正面衝突する流れ場であり、中央の渦によ って、二つの噴流は互いに相手を自分の方へ引き込むような形をと る。流速が大きくなるにつれて、中央部の非定常な脈動による濃度 変化が激しくなる傾向がある。小さな渦が目立たなくなる一方、全 体的に大きな渦が観察される。低周波の乱流による混合が促進され、 運動量の輸送方向が $90^{\circ}$ 変化するので、混合状態が比較的よい。

\section{[CASE2】}

基本的には、直角に衝突する二つの角型噴流が両側に交互に渦を つくり、非定常な脈動を起こすという流れ場である。左側にできる 渦は、チャンバーの上下部分を通って右側に現れる。 $\mathrm{Re}=10000$ 程 度では、その効果は薄く、混合の程度は十分ではない。 $R e=20000$ になると、速度分布の最大值が中央寄りに移動して、乱流混合に若 干の改善が見られる。

\section{[CASE3]}

CASE2 と同様に二つの角型噴流が直角に衝突する流れ場である。 当初から最も混合効率が良いと予測された。実際の流れにおいては、 低速では煙が両側に偏り、高速では脈動による混合濃度の変化がチ ヤンバー内で目立った。しかし、フィルター通過後の流れの濃度は 一定で、タイムラインもあまり見えないほど均等な混合が行われる。 流れ場の時間変化が激しくなり、模様が左右対称でなくなることが 多くなる。噴流の衝突周りに起こった負圧部分に引き込まれた流れ が、広いスペースを使って混合するパターンである。

\section{[CASE4]}

二つの角型噴流が直角に衝突して、更に運動量方向を $90^{\circ}$ 変える 流れ場である。微妙に左右で濃淡が確認できるが、速度が上がると 左右の差は小さくなり、比較的安定した流れを形成する。混合効率 は CASE3 に及ばないが、チャンバー内での流れの安定度ではこち らの方が優れている。これも CASE3 と同じように、三つの噴流の 衝突周りの負圧部分による引き込みで混合するというパターンであ る。しかし、このケースでは脈動による濃度変化と偏りは少ない。

\section{【CASE5】}

平行な二つの角型噴流が運動量の方向を $90^{\circ}$ 変えて、そのまま平
行に流れる流れ場である。全くといっていいほど混合しない。その ため、内表面右側部分にはトレーサー煙の污れがほとんど付着しな い。写真では、フィルター通過後には混合しているように見えるが、 これはチャンバー出ロからの上昇気流がダクト周りの負圧部分によ って吸引されたものである。底面近くではほとんど混合しない：二 つの平行な流れが底面に衝突して、淀み点周辺で正圧部分が生まれ、 その周りに渦ができる。一点鎖線は正圧部分を表しており、脈動の 中心線でもある。

\section{[CASE6]}

平行な二つの噴流が運動量の方向を変えることなく直進する流れ 場である。二つの噴流の運動量方向に流出口があるので、混合状態 は最低である。境界層剪断乱流より、自由剪断乱流が平行して存在 している状態に近い。但し、平均流速が等しいため、平行する噴流 間の剪断力は小さい。流出口において噴流のポテンシャル・コアが 残り、噴流の運動量が保存された状態であると考えられる9!。噴流 の一部はダクト周りのバックステップの負圧部分に吸引されるが、

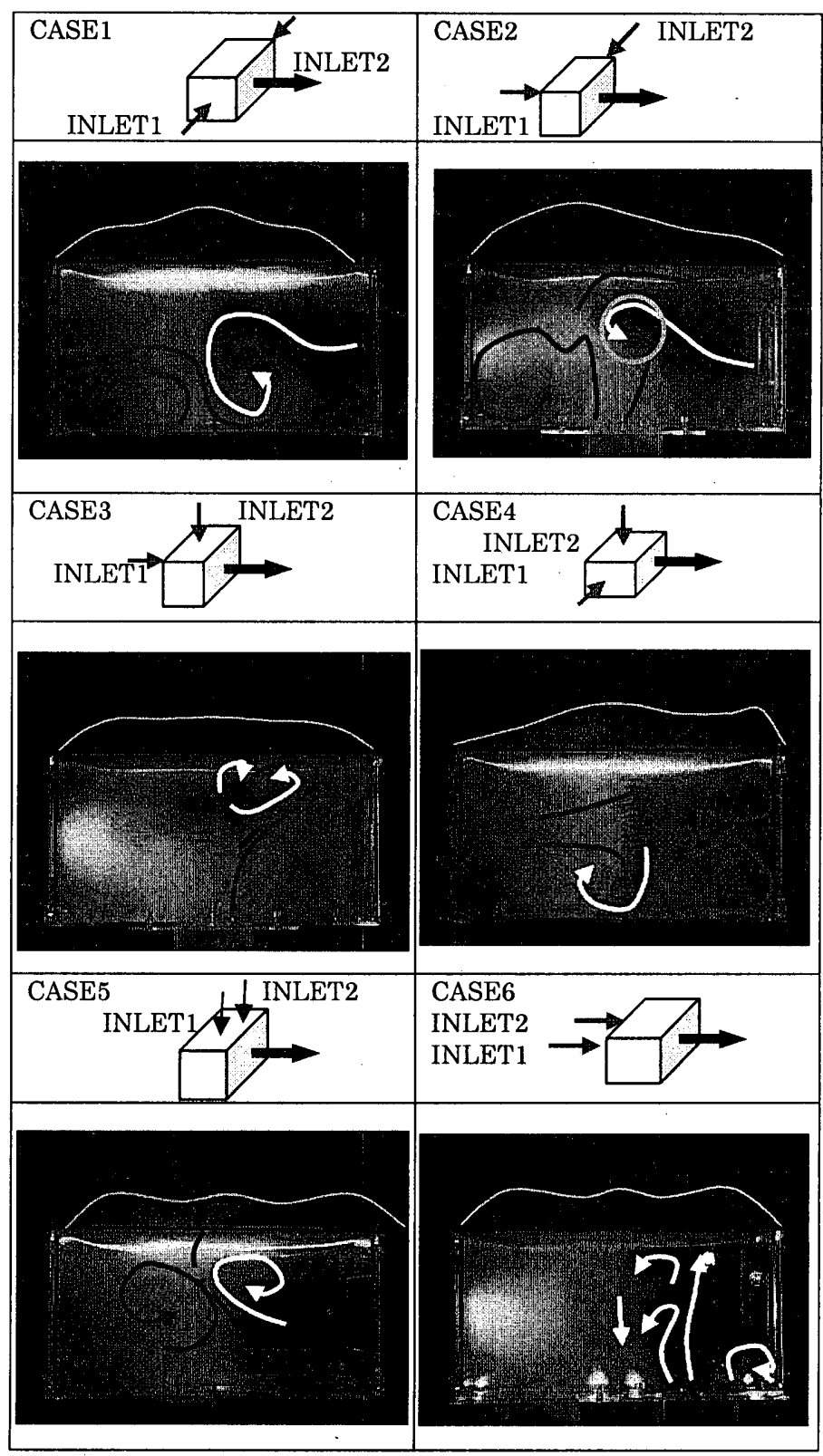

図 5 気流可視化実験結果 
ほとんどは流入と同時に流出してしまい、負圧部分の混合効果はな い。中心線周りに生じる負圧に一部引き込まれながら流れる。この ケースも CASE5 と同様、混合状態が悪い。流入流速が速くなるに つれて流れ場は複雑になるが、それは中心線前周りだけであり、最 後までほとんど混合しない。

\section{2 出口空気温度分布計測}

混合チャンバー出口で空気温度分布を計測した結果を表 1 と 2 に 示す。ここでは 60 分データの時間平均值を取り、上流側の外気と 還気の混合率 $\boldsymbol{k}$ を次式により評価する 2 。

$$
k=1-\frac{\max \left(\bar{t}_{M I X}\right)-\min \left(\bar{t}_{M I X}\right)}{\bar{t}_{O A}-\bar{t}_{R A}}
$$

ここで、

$\bar{t}_{M I X}$ : 混合チャンバー出口空気温度の時間平均値 $\left[{ }^{\circ} \mathrm{C}\right]$

$\bar{t}_{O A}$ : 外気温度 (高温側空気温度) の時間平均值 $\left[{ }^{\circ} \mathrm{C}\right]$

$\bar{t}_{R A}:$ 還気温度 (低温側空気温度) の時間平均值 $\left[{ }^{\circ} \mathrm{C}\right]$

である。式(5)において、記号 $\max$ 及び $\min$ は $\bar{t}_{M I X}$ の 21 点の空間 温度分布の最大值と最小值を示す。すなわち、混合の度合が良好で あれば混合率 $\mathrm{k}$ は 1 に近い值を示し、混合の度合が不十分であれば 0 に近い值を示すことになる。Robinson'2)は、空気混合装置の混合 効率を定義するときに、式(5)を”modified effectiveness rating”とし て評価基準に採用している。

表 1 から、CASE2 と 6 では、 $\mathrm{Re}=5000$ と比較して、Re=10000 以上では混合率が小さくなることがわかる。これは、レイノルズ数 が高くなるに伴って慣性力の影響が卓越することから、二つの噴流 が混合せずに流出する度合が高くなるためである。いずれのケース においても Re $=10000$ 以上では混合率のレイノルズ数依存性はほと んどない。いずれのレイノルズ数においても、混合率は CASE3 が 最大で、CASE6 が最小である。CASE5 と 6 は他のケースと比較し て混合率が低い。

表 2 から、同一のレイノルズ数では混合チャンバー出口空気温度 の標準偏差は CASE3 が最小で、CASE6 が最大であることがわかる。 出口空気温度の標準偏差は、出口空気温度分布の一様性を示すこと から、混合チャンバー出口空気温度分布は CASE3 が最小で、CASE6 が最大であると評価される。この結果は、各ケースにおける混合率 の評価と一致する。また、CASE2 と 6 では、 $R e=5000$ と比較して、 $\mathrm{Re}=10000$ 以上では標淮偏差が大きくなり、混合が悪くなることが わかる。この傾向も混合率において認められる傾向と同様であり、 両者の評価の相関が高いことが裏付けられる。

以上のように、混合チャンバーの出口空気温度分布から得られた 結果は、CASE3 の混合状態が最もよく、CASE6 が最も悪いという ものであり、気流可視化実験による観察結果と合致している。

\section{3 局部抵抗係数の実測}

実験ケースごとに INLET1 及び INLET2 内部の静圧と室内圧と の静圧差をピトー管により計測して求めた局部抵抗俰数を表 3 に示 す。ダクト内風速が小さいとき、差圧が正確に計測できないため、 ここでは Re=20000における実験結果のみを示すものとする。表 3 のデータは 3 回の繰り返し実験によって得られたデータの平均值で
表 1 各ケースにおける混合率

\begin{tabular}{|l|c|c|c|c|}
\hline & $\operatorname{Re}=5000$ & $\mathrm{Re}=10000$ & $\mathrm{Re}=15000$ & $\mathrm{Re}=20000$ \\
\hline CASE1 & 0.57 & 0.51 & 0.53 & 0.51 \\
\hline CASE2 & 0.50 & 0.35 & 0.37 & 0.40 \\
\hline CASE3 & 0.65 & 0.66 & 0.62 & 0.57 \\
\hline CASE4 & 0.47 & 0.43 & 0.43 & 0.42 \\
\hline CASE5 & 0.23 & 0.22 & 0.21 & 0.19 \\
\hline CASE6 & 0.16 & 0.10 & 0.08 & 0.07 \\
\hline
\end{tabular}

表 2 各ケースにおける混合チャンバー出口空気温度の標準偏差 単位 $\left[{ }^{\circ} \mathrm{C}\right]$

\begin{tabular}{|l|c|c|c|c|}
\hline & $\operatorname{Re}=5000$ & $\mathrm{Re}=10000$ & $\mathrm{Re}=15000$ & $\mathrm{Re}=20000$ \\
\hline CASE1 & 2.54 & 2.53 & 2.82 & 3.06 \\
\hline CASE2 & 2.56 & 3.72 & 3.66 & 3.15 \\
\hline CASE3 & 1.75 & 1.85 & 1.94 & 2.08 \\
\hline CASE4 & 3.26 & 3.25 & 3.06 & 3.26 \\
\hline CASE5 & 5.07 & 5.14 & 5.09 & 5.20 \\
\hline CASE6 & 5.22 & 5.96 & 6.79 & 6.83 \\
\hline
\end{tabular}

表 3 局部抵抗係数と総合抵抗係数 $(R e=20000)$

\begin{tabular}{|l|c|c|c|}
\hline & 局部抵抗係数1 & 局部抵抗係数2 & 総合抵抗係数 \\
\hline CASE1 & 1.04 & 1.09 & 4.01 \\
\hline CASE2 & 0.76 & 0.57 & 3.21 \\
\hline CASE3 & 0.77 & 0.54 & 3.20 \\
\hline CASE4 & 0.77 & 0.89 & 3.54 \\
\hline CASE5 & 0.79 & 0.73 & 3.39 \\
\hline CASE6 & 0.53 & 0.49 & 2.90 \\
\hline
\end{tabular}

あり、6 個のケース（6 水準間）について F 検定を行うと、危険率 $1 \%$ で有意差が認められる。

局部抵抗係数 $1\left(\zeta_{1}\right)$ 及び局部抵抗係数 $2\left(\zeta_{2}\right)$ と総合抵抗係数

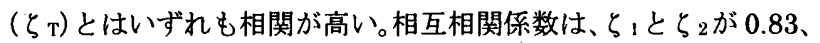

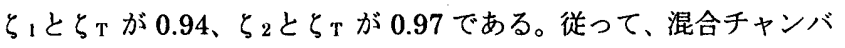
一の圧力損失を後者で評価することが可能である。

ここで、総合抵抗係数が最も小さいのは CASE6 であり、次に小 さいのは CASE2 と 3 である。逆に最も大きいのは CASE1である。 CASE6 では二つの角型噴流が直進するため、運動量の損失が少な く、局部抵抗倸数及び総合抵抗係数が小さい。CASE1 では噴流が 正面衝突をして運動量が大きく失われることから、局部抵抗棌数及 び総合抵抗係数が大きくなるものと考えられる。CASE2 及び 3 で は、片方の噴流は直進することから、運動量の損失が比較的小さく、 それが局部抵抗係数及び総合抵抗係数に反映されている。

\section{CFDによる検討}

実験結果と比較するために、CFD を用いて対象とする混合チャ ンバーの気流解析を行う。ここでは有限体積法により 3 次元非圧縮 性 Navier-Stokes 方程式を離散化して数值計算を行う。乱流モデル としては標準 $\mathbf{k} \cdot \varepsilon$ モデルを用いる。また、高レイノルズ数流れを解 くための上流化手法には、QUICK（3 次精度）を採用する。

模型実験と同じケース分けによって、混合チャンバーに外気取入 ダクトと還気ダクトを接続する。混合チャンバーの寸法は、400W $\times 200 \mathrm{H} \times 200 \mathrm{D}$ とし、それに接続するダクト寸法を $100 \times 100$ の断 面、長さ $450 \mathrm{~mm}$ とする。混合チャンバーに外気ダクトと還気ダク トが接続された領域を計算領域とする。

表 4 に数值シミュレーションの計算条件を示す。混合チャンバー 
に流入するダクト内気流のレイノルズ数が $\mathrm{Re}=10^{4}$ になるようにダ クト内風速を設定する。

以上のように、CFD により、模型実験と同一の条件で二つの角 型噴流の混合を再現する。

図 6 にCFD による混合チャンバー出ロの温度コンターを示す。 CASE3 では中心付近で温度コンターが大きく閉じており、温度分 布も小さいことから、うまく気流が混合していることがわかる。こ れは、気流可視化実験で観察された結果と同様である。CASE5 と CASE6 では温度コンターが中央部で綎方向に近接して並んで、温 度分布が左右で大きく、ほとんど混合しない。CASE5 と 6 は二つ の噴流が平行して流入するため、気流可視化実験結果と同様に左右 に分離した流れ場が観察できる。CASE1 では、温度コンターが水 平に並んでいるが、間隔が比較的広く、温度分布は小さい。これは 二つの噴流が正面衝突するためであり、気流可視化実験の観察と照 合できる。CASE2 では、左側に温度コンターの閉じた部分があり、 中央部に垂直に温度コンターが広い間隔で並んでいて、左右で気流 が分離している。温度コンターの閉じた部分は、二つの噴流の衝突 による渦であると考えられ、気流可視化実験でも同様の観察がされ ている。CASE4 では、右側に温度コンターがほぼ閉じた部分があ り、左右で気流が分離する傾向にある。温度コンターがほぼ閉じた 部分は、気流可視化実験で観察された負圧部分であると考えられる。

表 5 に CFD による混合率と実験結果を対比して示す。6 ケース の混合率は、CFD と実験結果では数值的には差が大きいが、 $\mathrm{k}(\mathrm{CFD})$ と $\mathrm{k}(\mathrm{EXP}$.$) 相関係数は 0.97$ であり、両者の相関が高いことがわか る。従って、接続方法の良否を判断するために、混合率で評価する ことは妥当であると考えられる。CFDによる混合率で評価すると、 CASE3 が最大であり、次に大きいのは CASE1 と CASE4 である。 逆に CASE5 と CASE6 では混合率が極めて小さい。この傾向は、 実験で求めた混合率の傾向と同様である。また、CFDによる混合率 の傾向と CFD の温度コンターを観察した結果とは一致している。 実験結果から、運動量の損失が小さい CASE6 は局部抵抗俰数が小 さいが混合しにくい一方で、運動量の損失が大きい CASE1 は局部 抵抗係数が大きいが混合しやすい。CASE2 から 5 は、CASE1 と CASE6 の中間に位置する。この実験結果と、CFDによる混合率の 相関も認められる。

\section{5. 評洒}

以上の実験結果及び CFD の結果から、混合チャンバーのダクト 接続方法について総合的な評価を行う。

気流可視化実験から判断すると、二つの流入気流の混合状態に関 しては、CASE2、3、4が最も好ましく、CASE1 は流れが脈動して いて不安定であり、CASE5 と 6 は混合が好ましくないという観察 結果になる。

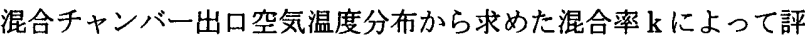
価すると、CASE3 が最大で、CASE6 が最小となる。混合チャンバ 一出口空気温度の標準偏差から評価すると、CASE3 が最小で、 CASE6 が最大となる。従って、CASE3 は混合状態が最もよく、 CASE6 が最も悪いことになる。

総合抵抗係数で評価すると、CASE6 が最小であり、次に小さい のは CASE2 と 3 である。逆に最大は CASE1 である。
表 4 計算条件

\begin{tabular}{|c|c|c|}
\hline \multirow{2}{*}{ 流 入 } & 外気 & $\left.1.51[\mathrm{~m} / \mathrm{s}] ; 40.0{ }^{\circ} \mathrm{C}\right]$ \\
\hline & 還 気 & $\left.1.51[\mathrm{~m} / \mathrm{s}], 25.0{ }^{\circ} \mathrm{C}\right]$ \\
\hline 流 出 & 混合チャンバー出ロ & 自然流入流出 \\
\hline \multicolumn{2}{|c|}{ 壁 面 } & (速度) 一般化対数則 \\
\hline $\begin{array}{l}\text { 流入境界条件としての乱流工 } \\
\text { を用いて求める。 }\end{array}$ & 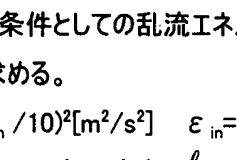 & $09^{3 / 4} \cdot k_{\text {in }}{ }^{3 / 2} / \ell_{m}\left[\mathrm{~m}^{2} / \mathrm{s}^{3}\right]$ \\
\hline \multicolumn{3}{|c|}{ ここで、 $U_{\text {in }}$ 流入速度、 $\ell_{m}=1 / 2 \mathrm{~L} 、$ ：吹出短辺 } \\
\hline \multicolumn{2}{|c|}{ 移流項差分スキーム } & QUICK（3 次精度） \\
\hline \multicolumn{2}{|c|}{ 乱流モデル } & 標準 $k-\varepsilon$ モデル \\
\hline \multirow{6}{*}{ 計算メッシュ } & CASE1 & $54(x) \times 40(y) \times 11(z)$ \\
\hline & CASE2 & $54(x) \times 40(y) \times 11(z)$ \\
\hline & CASE3 & $25(x) \times 54(y) \times 29(z)$ \\
\hline & CASE 4 & $45(x) \times 38(y) \times 27(z)$ \\
\hline & CASE5 & $21(x) \times 40(y) \times 32(z)$ \\
\hline & CASE6 & $21(x) \times 57(y) \times 11(z)$ \\
\hline
\end{tabular}

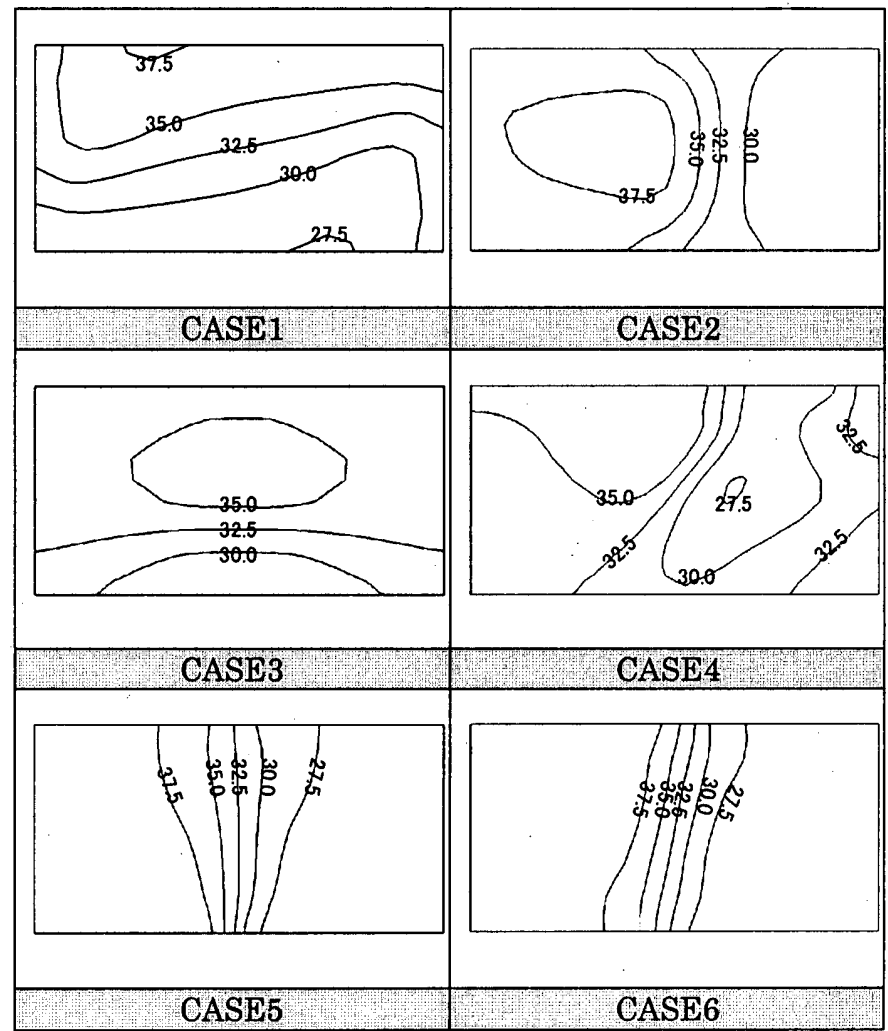

図 6 混合チャンバー出口の温度コンター

表 5 CFDによる混合率

\begin{tabular}{|l|l|l|r|r|}
\hline & $\mathrm{T}_{\min }$ & $\mathrm{T}_{\max }$ & $\mathrm{k}(\mathrm{CFD})$ & $\mathrm{k}(\mathrm{EXP})$ \\
\hline CASE1 & 27.22 & 37.77 & 0.296 & 0.51 \\
\hline CASE2 & 27.22 & 38.70 & 0.235 & 0.35 \\
\hline CASE3 & 28.02 & 37.13 & 0.392 & 0.66 \\
\hline CASE4 & 26.90 & 37.88 & 0.268 & 0.43 \\
\hline CASE5 & 25.17 & 39.77 & 0.026 & 0.22 \\
\hline CASE6 & 25.02 & 39.98 & 0.003 & 0.1 \\
\hline
\end{tabular}


CFD による結果から混合チャンバー出口の温度コンターと混合 率で評価すると、混合チャンバーのダクト接続方法としては、 CASE3 が最も好ましく、CASE5 と CASE6 は避けるべきであるこ とがわかる。

以上の評価を表 6 にまとめて示す。表 6 に示す 4 項目の評価は、 概ね高い相関がある。模型実験及び CFD の結果から、混合チャン バーのダクト接続方法としては、CASE3 が最も好ましく、CASE5 と CASE6 は避けるべきであることがわかった。

CASE5 と CASE6 は還気ダクトと外気取入ダクトを混合チャン バーの同じ面に並べて接続する方法であり、空調機械室の納まりが 厳しいときにはこの接続方法で施工される可能性がある。しかし、 混合チャンバーの混合特性を考慮すると、これらの接続方法を採用 すべきではない。また、CASE1 のように混合チャンバーの両側面 からダクトが接続される方法も好ましくないが、ダクトの納まり上 から考えると、この接続方法は採用されにくいと思われる。

\section{6. まとめ}

エアハンドリング・ユニットの混合チャンバーにおける外気ダク トと還気ダクトの接続方法の良否を評価するために、模型実験及び CFDによる検討を行い、次の結論を得た。

(1) 流動パラフィン煙をトレーサーに用いた気流可視化実験の結果、 CASE2、3、4が好ましく、CASE1、5、6 は好ましくない。 (2)混合率 $\mathbf{k}$ 及び出口空気温度分布によって評価すると、CASE3 が 最も好ましく、CASE6 が最も好ましくない。 (3)総合抵抗係数で評価すると、CASE6、2、3 が好ましく、CASE1 は好ましくない。

(4)CFD により温度コンターを観察した結果と混合率を比較した結 果から、CASE3 が最も好ましく、CASE6 が最も好ましくない。 (5)総合評価を行うと、混合チャンバーのダクト接続方法としては、 CASE3 が最も好ましく、CASE5 と CASE6 は避けるべきである。

今回の検討では INLET1 と 2 の流量比を $1: 1$ としたが、この比率 が大きく変化したとき、二つの気流の混合に改善が見られる可能性 がある。

本報では流量比 1:1 の条件で模型実験と CFD により混合チャン バーのダクト接続方法について検討を行ったが、将来の研究として は㬰大実験あるいは現場実測により本研究の妥当性を実証する予定 である。

\section{謝辞}

本論文における実験に際し、東海大学工学部動力機械工学科山本 高志氏（当時）及び日本大学生産工学部数理工学科桜井太郎氏（当 時）には多大なる協力を頂くことができたことに深く謝意を表す。

\section{【参考文献】}

1）（社）空気調和・衛生工学会編：空気調和衛生工学便覽第 12 版第 2 巻 (1995)

2) Keith D. Robinson, Rating Air-Mixing Equipment, ASHRAE Journal Vol.42 No.2, 2000

3) Keith D. Robinson, Damper Control Characteristics and Mixing nit on $\mathbf{r}$,
表 6 混合チャンバーの評価

\begin{tabular}{|l|c|c|c|c|}
\hline & $\begin{array}{c}\text { 気流可視化 } \\
\text { (実験) }\end{array}$ & $\begin{array}{c}\text { 混合率 } \\
\text { (実験) }\end{array}$ & $\begin{array}{c}\text { 総合抵抗係数 } \\
\text { (実験) }\end{array}$ & $\begin{array}{c}\text { 混合率 } \\
\text { (CFD) }\end{array}$ \\
\hline CASE1 & $\times$ & $\Delta$ & $\times$ & $\Delta$ \\
\hline CASE2 & 0 & $\Delta$ & 0 & $\Delta$ \\
\hline CASE3 & 0 & $\bigcirc$ & 0 & $\bigcirc$ \\
\hline CASE4 & $\bigcirc$ & $\Delta$ & $\Delta$ & $\Delta$ \\
\hline CASE5 & $\times$ & $\Delta$ & $\Delta$ & $\times$ \\
\hline CASE6 & $\times$ & $\times$ & 0 & $\times$ \\
\hline
\end{tabular}

Effectiveness of an Air-handling Unit Combination Mixing/filter ASHRAE Trans., Vol.104 Pt.1A, pp629·637, 1998

4) Keith D. Robinson, Mixing Effectiveness of AHU Combination Mixing/filter Box with and without Filters, ASHRAE Trans., Vol.105 Pt.1, pp88-95, 1999

5）橋本幸博、柳原茂、登坂宣好：混合チャンバーの空気力学的特性（その 1) 混合特性の評価、日本建築学会大会学術講演梗概集 環境工学 II pp613-614, 2001

6）柳原茂、橋本幸博、登坂宣好：混合チャンバーの空気力学的特性（その 2) 抵抗係数の評価と総合評価、日本建築学会大会学術講演梗概集 環境工学 II pp615·616, 2001

7）橋本幸博、吉野一、柳原茂、登坂宣好 : 混合チャンバーの空気力学的特性 （その 3) CFD と実験結果の比較、日本建築学会大会学術講演梗概集 環境 工学 II pp811·812, 2002

8）日本機械学会: 技術資料 管路・ダクトの流体抵抗、pp53-105 丸善、1991 9） N. ラジャラトナム原著、野村安正訳 : 噴流、pp272-279、森北出版、1981 10）日野幹雄：流体力学、pp330·439、朝倉書店、1992

\section{Appendix}

図 Aに示すように、混合チャンバーに流入する流れについて、代 表的な流線を考える。流線 1 及び流線 2 について、以下のベルヌー イの式が成り立つ。但し、混合チャンバー出口の静圧及び流速は等 しいものとする。

$$
\begin{aligned}
& p_{1}+\frac{1}{2} \rho v_{1}^{2}=p_{0}+\frac{1}{2} \rho v_{0}^{2}+\Delta p_{1} \\
& p_{2}+\frac{1}{2} \rho v_{2}^{2}=p_{0}+\frac{1}{2} \rho v_{0}^{2}+\Delta p_{2} \\
& \Delta p_{T}=\Delta p_{1}+\Delta p_{2}=\left(p_{1}-p_{0}\right)+\left(p_{2}-p_{0}\right)+\frac{1}{2} \rho\left\{\left(v_{1}^{2}+v_{2}^{2}\right)-2 v_{0}^{2}\right\} \\
& \Delta p_{T}=\Delta p_{1}+\Delta p_{2}=\Delta p_{s 1}+\Delta p_{s 2}+\frac{1}{2} \rho\left\{\left(v_{1}^{2}+v_{2}^{2}\right)-2 v_{0}^{2}\right\}
\end{aligned}
$$

ここで、 $\Delta \mathrm{p}_{1}$ 及び $\Delta \mathrm{p}_{2}$ は流線 1 及び 2 における圧力損失であり、 それ以外の記号はすでに定義した物理量である。

流線 2

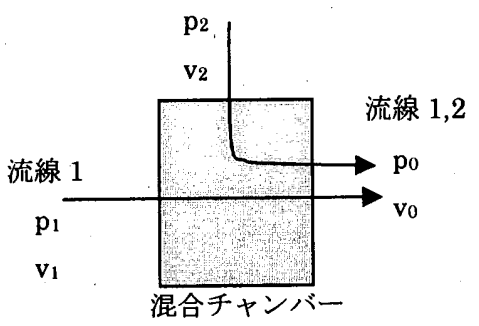

図 A 混合チャンバーにおける流線

(2004年 2 月 2 日原稿受理，2004年 5 月11日採用決定) 